\title{
DINAMIKA PEKERJA MUDA OUTSOURCING: KEGEMBIRAAN DAN KERENTANAN MENUJU RISIKO MASA DEPAN
}

\author{
Ridwan Tajul Fahmi ( $\left.{ }^{*}\right)$, Nanda Harda Pratama Meiji (2), Nur Hadi ( ${ }^{3}$ ) \\ ${ }^{123}$ Faculty of Social Science, Universitas Negeri Malang, East Java, Indonesia
}

\section{ARTICLE INFORMATION}

$\begin{array}{ll}\text { Submitted } & : 21^{\text {st }} \text { November, } 2020 \\ \text { Review } & : 15^{\text {th }} \text { April, } 2021 \\ \text { Accepted } & : 18^{\text {th }} \text { May, } 2021 \\ \text { Published } & : 07^{\text {th }} \text { June, } 2021 \\ \text { Available Online } & : \text { June, } 2021\end{array}$

\section{KEYWORDS}

Youth; Transition; Outsourcing; Risk.

\section{CORRESPONDENCE}

E-mail: ridwan.tajul.1707516@students.um.ac.id

A B S T R A C T
Working is one of the hopes as well as an achievement for the transitional
period of youth. The social, cultural, and economic contexts that are developing
rapidly due to globalization and advances in science and technology have made
the sphere of work also change. As a result, the outsourcing work system has
become the right choice for young people to develop their careers. Using
qualitative research methods with a biographical model, several young
informants were selected to tell narratives related to their dynamic careers in
several industries with an outsourcing system. Data were collected through in-
depth interviews and observations on the activities carried out by these young
workers-besides, some secondary data related to the world of work as the
primary data support. From the results obtained, youth who work in the
industrial sector with an outsourcing mechanism have quite a risk of being
vulnerable in the future even though the transition period they are experiencing
looks relatively smooth (after taking education directly to work). Their joy in their
daily lives as young people seems to be able to encourage them to keep their
enthusiasm for work even though the risks that exist in the future are uncertain
and winding.

\section{A. PENDAHULUAN}

$\mathrm{R}$

anah kerja di berbagai pelosok dunia saat ini telah mengalami berbagai macam perubahan yang cukup signifikan, terutama paska revolusi industri 4.0 yang menjadikan IPTEK sebagai acuan. Setiap individu berlombalomba untuk mencari pekerjaan dan mendapatkan impian yang diidam-idamkan. Terlebih dalam konteks hari ini dimana dunia seakan berlari kencang dan perubahan dapat terjadi dengan cepat (Alves et al., 2014; Anthony Giddens, 2002). Oleh sebab itu individu dan kelompok mesti beradaptasi dengan tantangan perubahan yang dinamis tersebut. Salah satu dampak dari revolusi industry 4.0 adalah mengaburnya Batasan-batasan negara dalam banyak sektor, yang lebih dikenal dengan istilah Globalisasi.

Globalisasi membuat segala hal menjadi lebih mudah dan instan namun pada sisi lain tidak dapat dipungkiri bahwasanya globalisasi juga memiliki dampak negatif (Bonnett, 2005; Ritzer, 2008). Dampak negatif yang ditimbulkan globalisasi salah satunya adalah pemilik usaha kecil akan kalah dengan usaha besar yang memiliki akomulasi modal yang besar, baik yang berasal dari dalan negeri ataupun luar negeri (Haji Mohamed, 2017). Oleh karena itu perubahan akibat globalisasi dihadapi dengan lebih tepat dan dilihat sebagai sebuah kesempatan untuk perubahan ke arah yang lebih baik. Sebagaimana dijelaskan oleh Beck bahwa globalisasi sebenarnya dapat berubah menjadi sebuah risiko kesempatan untuk perbaikan umat manusia dan juga pada domain yang lain dapat menjadi sebuah bencana (Beck, 2009; Clarke \& Beck, 2006). Globalisasi pada akhirnya memberikan dampaknya pada sisi dunia kerja yang semakin penuh dengan serba ketidakpastian (Anthony Giddens, 2002; Hull et al., 2009; Ritzer, 2008). 
Berdasarkan data yang dikeluarkan oleh ILO menunjukkan bahwasanya angka partisipasi kerja angkatan muda (15-24 tahun) justru menurun meskipun angka populasinya merangkak naik (Summary, 2020). Hal ini menunjukkan bahwasanya masih perlu banyak perbaikan dalam dunia kerja yang nantinya dapat memberikan alternatif pekerjaan bagi para pencari kerja muda, mengingat kebanyakan dari anak muda paska menyelesaikan pendidikan bertujuan untuk bekerja (Sutopo \& Azca, 2013; Sutopo \& Meiji, 2017). Jumlah Iapangan pekerjaan justru tidak berimbang apabila dibandingkan dengan jumlah angkatan yang siap kerja (Badan Pusat Statistik, 2019). Alhasil jumlah anak muda yang berada di dalam kategori NEET (not in employment, education, or training) cenderung meningkat setiap tahun. Hal ini tentu akan menjadi sebuah permasalahan yang berlarutlarut apabila dibiarkan. Terlebih Indonesia memproyeksikan diri dalam Indonesia Emas 2045 yang berusaha mengoptimalkan bonus demografi setelah 100 tahun merdeka.

Sulitnya mencari lapangan pekerjaan yang sesuai dengan kriteria pendidikan membuat anakanak muda mulai terombang-ambing dalam status sebagai penganggur terbuka. Namun rupanya kini mekanisme sistem outsourcing menjadi salah satu alternatif pilihan dimana anak-anak muda mulai memilih untuk melanjutkan karir mereka pada beberapa industri yang tersebar di beberapa kota besar. Industrialisasi sendiri dapat di artikan sebagai kegiatan yang mengubah sesuatu barang dasar dengan teknologi pengeloahan yang tinggi, untuk kemudian dijadikan menjadi barang jadi (Bima et al., 2020). Jawa Timur sebagai salah satu provinsi yang memiliki perkembangan pembangunan cukup pesat juga menjadi salah satu destinasi penting bagi industry-industri baik tingkat internasional maupun nasional guna mengembangkan aspek bisnis mereka (BPS Jatim, 2019). Kota-kota satelit di sekeliling Surabaya seperti Sidoarjo, Gresik, Pasuruan, dan Mojekerto pun menjadi destinasi bagi para pemilik modal untuk membangun dan mengembangkan usahanya. Hal ini yang kemudian menjadi tawaran baru bagi para pekerja-pekerja muda di sekitar Jawa Timur untuk berpartisipasi kerja di dalamnya.

Apabila dulunya wilayah-wilayah industri yang ada di sekitar Surabaya merupakan lahan pertanian dan perkebunan, kini paska industri masuk mulai berdiri banyak macam industri dengan berbagai model komoditas. Hal tersebut secara tidak langsung juga memperlihatkan adanya perubahan sosial akibat proses globalisasi di wilayah Jawa Timur. Dampaknya tentunya bukan hanya sebatas pembangunan fisik namun juga pada aspek sosial masyarakatnya. Salah satunya adalah bagaimana pemuda lebih tertarik bekerja di industri daripada melanjutkan karir di bidang lainnya seperti pertanian. Sebagaimana penjelasan Ben White bagaimana anak-anak muda mulai mengalihkan isu pekerjaan mereka pada jenis pekerjaan yang dianggap lebih menarik daripada hanya sekedar menjadi seorang "petani" (Naafs \& White, 2012; White, 2011, 2015). Tentunya masih banyak persoalan lain seperti bagaimana jumlah lahan pertanian yang terus menurun (Duncan, 2017; Susilowati, 2016; White, 2013) dan juga pembangunan pemerintah yang mengandalkan sektor-sektor industri sejak era orde baru (Hadiz, 2006). Hal ini kemudian membuat masa depan dunia kerja anak muda seolah telah ditetapkan untuk memasuki ranah industri.

Salah satu isu yang menjadi menarik adalah model penerapan outsourcing yang makin kian berkembang dan menyebar di dunia kerja saat ini. Melalui UU nomor 13 tahun 2003 tentang ketenagakerjaan, system outsourcing mulai semakin membuat Indonesia (baik pemerintah maupun pemilik modal) fleksibel dalam mengatur pasar tenaga kerja. Lantas bagaimana mekanisme outsourcing tersebut dilakukan? Model outsourcing atau juga kadang disebut alih daya yakni menggunakan pihak ketiga sebagai pemasok dan pengelola tenaga kerja kontrak guna masuk di dalam perusahaan (Hendrastomo, 2010). Jadi dunia industri melalui pihak ketiga mempekerjakan buruh di sistem mereka berbasis kontrak yang diperbaharui dalam kurun waktu tertentu. Hal ini pula yang dialami oleh anak-anak muda asal Mojokerto yang notabenenya sebagai kota satelit, juga merupakan penghasil tenaga kerja utama bagi industri-industri di Jawa Timur terutama di wilayah Surabaya dan sekitarnya.

Anak-anak muda asal Mojekerto juga memiliki keinginan yang sama dimana mereka berusaha untuk menggapai impian mereka di masa depan. Transisi yang mereka inginkan memang tidaklah mulus sebagaimana pemuda-pemuda yang ada di belahan wilayah lain di Indonesia (Sutopo \& Meiji, 2017, 2014b). Rerata anak-anak muda ini memilih untuk melanjutkan fase transisi mereka ke dunia kerja melalui mekanisme outsourcing melalui agenagen yang ada di sekitar mereka. Jenis pendidikan yang diambil oleh anak-anak muda ini pun pada akhirnya menjurus pada model yang siap kerja seperti SMK daripada SMA. Hal ini karena melalui SMK, mereka memiliki harapan untuk langsung masuk ke fase transisi berikutnya di ranah dunia kerja. Hal ini juga didukung oleh data ILO yang menyatakan bahwasanya pendidikan dengan model vokasi lebih diminati secara umum daripada pendidikan formal (Summary, 2020). Keputusan tersebut juga merupakan bentuk bahwasanya sekolah model vokasi mampu memberikan tawaran kerja lebih menarik paska lulus ketimbang menambah waktu dalam dunia pendidikan.

Berangkat dari realitas sosial yang terjadi pada anak-anak muda tersebut, peneliti berusaha untuk menelaah dan menggali dimensi isu ketenagakerjaan dalam konteks outsourcing pada anak-anak muda di wilayah Mojokerto. Secara umum penelitian terkait buruh muda dalam konteks outsourcing masih belum banyak dilakukan. Namun memang mulai bermunculan penelitian tentang 
pemuda dan dunia kerja dalam konteks perburuhan seperti yang digambarkan oleh Oki terkait reproduksi sosial di wilayah Jawa Tengah (Sutopo et al., 2019). Sementara pada penelitian pemuda yang lainnya, Oki dan Nanda lebih menjabarkan perihal transisi dunia kerja pada konteks kepemudaan di Indonesia (Sutopo \& Meiji, 2017, 2014b). Oleh sebab itu analisa terkait transisi dan konteks risiko di masa depan akan dicoba digunakan oleh peneliti dalam menelaah kajian penelitian kali ini.

\section{B. METODE PENELITIAN}

$\mathrm{M}$ etode yang diguanakan dalam penelitian ini adalah metode kualitatif. Hal ini dimaksudkan untuk mengetahui gambaran yang tepat dan mendalam dari sudut pandang pemuda outsourcing di Mojokerto dalam masa transisinya menuju dunia kerja dan aspirasi mereka dalam meraih masa depan. Pendekatan kulitatif merupakan alat bantu yang baik dalam memahami dan menyajikan kehidupan sosial dari masyarakat yang diteliti dari sudut pandang masyarakat tersebut (Moleong, 2015). Metode penelitian ini dipilih karena sesuai dengan tujuan dan dan fenomena sosial yang hendak diteliti. Motode pengumpulan data yang digunakan adalah wawancara mendalam dan juga observasi. Informan penelitian dipilih secara Purposive dengan menyaratkan mereka yang bekerja di perusahaan outsourcing. Umur informan dibatasi dari usia 16 sampai 30 tahun, sesuai dengan peraturan UU Kepemudaan No. 40 Tahun 2009. Informan berjumlah 8 orang (5 laki-laki dan 3 perempuan). Informan tidak di batasi dari perusahaan tertentu, hal ini dimaksudkan untuk mengatahui perbedaan kebijakan perusahaan kepada pekerjanya, sistem kontrak dan juga kebijakan ketenagakerjaan lainnya. Uji validitas data dilakukan dengan triangulasi sumber. Analisi data dilakukan dengan tahapan pengumpulan data, reduksi data, dan penyajian data yang disajikan secara baik dan terstruktur.

Pendekatan Biografi Life History (kisah hidup) dalam penelitian ini dilakukan untuk mengetahui kisah hidup pemuda pekerja outsourcing dari masa mereka sekolah, dan dalam proses mereka mencari pekerjaan. Pendekatan ini memungkinkan peneliti untuk memperoleh data kisah hidup masa lalu informan. Data tentang masa lalu penting untuk di ketahui karena apa yang terjadi pada informan saat ini sangat terkait dengan masa lalu informan (Bertaux, 1981). Pendekatan life history juga memingkinkan untuk peneliti mengetahu bagaimana masa transisi pemuda dari sudut pandang pemuda sebagai individu dan sebagai anggota dari masyarakat.

\section{HASIL DAN PEMBAHASAN \\ 1. Transisi Pemuda Outsourcing}

$\mathrm{P}$ emuda dalam masa mudanya menghadapi fase penting dalam hidupnya, fase dimana mereka akan mengalami transisi dari fase sekolah menuju fase dunia kerja (A. Furlong \& Cartmel, 1997). Fase transisi yang dilakukan oleh pemuda menentukan bagaimana kehidupan dewasa mereka. Pemuda harus mampu beradapatasi dengan baik dalam memasuki fase baru dalam kehidupannya. Fase muda bukanlah fase yang mudah untuk di taklukkan oleh pemuda, dalam kajian psikologi masa muda adalah masa strom and struggle (Sutopo \& Azca, 2013). Guncangan dalam diri pemuda di sebabkan karena pemuda sedang melakukan eksperimen dengan identitas kedewasaan yang sedang mereka miliki. Dari sudut pandang yang berbeda, sosiologi melihat transisi pemuda menuju fase dewasa mereka dengan cara melewati tiga institusi sosial, yaitu pendidikan, keluarga dan kerja (Sutopo \& Meiji, 2014a). Pemuda harus beradaptasi dengan ketiga institusi sosial tersebut dengan baik, untuk memperoleh fase dewasa yang layak.

Fase transisi yang di lewati pemuda, tidak selalu lancar dan mudah. Banyak faktor yang mempengaruhi lancar atau tidaknya transisi pemuda, antara lain dorongan pribadi, faktor ekonomi dan faktor sosial. Faktor lain yang mempengaruhi transisi pemuda dari fase sekolah menuju fase dunia kerja adalah lapangan pekerjaan yang sangat terbatas. Keadaan tersebut di alami oleh pemuda outsourcing di Mojokerto. Tidak dapat di pungkiri hal tersebut mempegaruhi transisi pemuda outsourcing menuju fase kerja semakin sulit.

Dorongan pribadi dapat mempegaruhi fase transisi pemuda outsourcing di Mojokerto. Keinginan untuk memiliki pekerjaan, mencari pengalaman dan tidak ingin menjadi beban orang tua menjadikan pemuda lebih memilih untuk bekerja di pabrik. Seperti yang sudah dijelaskan oleh Lutfimansyah

\section{"Dulu setelah saya lulus SMK langsung berkenginan untuk mencari pengalaman terlebih dahulu. Akhirnya di beritahu teman ada lowongan pada pada pabrik tersebut. ya akhirnya saya daftar dan alhamdulillahnya diterima" (Wawancara Lutfimansyah, februari 2020).}

Informan tidak mengalami kesulitan dalam proses pencariaan kerja dalam sistem kerja outsourcing. Tidak ada tes, atau syarat khusus dalam proses mendaftarkan diri mereka dalam lowongan kerja outsourcing tersebut. Namun, pilihan untuk tidak melanjutkan pendidikan dapat menjadi hambatan mereka dalam masa transisi mereka. Walaupun pendidikan tidak menjamin kesuksesan karir dalam hidup namun pendidikan tinggi mampu menjadi jembatan untuk pekerjaan yang lebih baik 
(Andy Furlong \& Cartmel, 2007). Dengan pendidikan informan saat ini pilihan kerja yang dapat dipilih informan adalah bekerja dalam sistem kerja outsourcing.

Pada beberapa pemuda, mencari pengalaman dalam dunia kerja adalah hal yang di prioritaskan. Terlepas dengan bayaran yang diterima dan jenis pekerjaan yang akan mereka dapatkan. Nurul Huda menjelaskan bahwasannya dalam proses pencarian kerja, informan tidak mementingkan bayaran yang akan di terima yang penting mendapatkan pekerjaan terlebih dahulu

"Dulu ketika saya lulus SMK, saya sama temen saya iseng jalan-jalan, mana ada pabrik yang membutuhkan karyawan di bidang produksilah waktu itu saya ke CV. Hasil Karya coba tanya ternyata ada, tapi ikut CV penyalur tenaga kerja. Akhirnya saya putuskan untuk mencoba ajalah, terlepas itu kerjannya gimana upahnya berapa saya kesampingkan, yang penting dapet pengalaman" (Wawancara Nur Huda, Februari 2020).

Idialisme yang muncul dari diri pemuda
mengindikasikan bahwa mereka sedang bereksperimen dengan masa transisi menuju dunia kerja. Pertimbangan yang seberanya harus dipikirkan pemuda dalam mencari kerja adalah apakah pekerjaan itu layak dan dapat meminimalisi risiko yang akan mereka terima di masa depan. pemuda outsourcing cenderung kurang mempersiapkan diri mereka untuk menghadapai risiko di masa modern lanjut ini. Berbeda dengan masa modern awal yang semuanya mudah di tebak dan terencana, pada masa era modern lanjut terdapat banyak sekali risiko dan ketidakpastian yang di sebabkan perubahan sosial yang besar di masyarakat (Beck, 1992).

Transisi pemuda outsourcing juga di pengaruhi keadaan ekonomi pemuda. Banyak pemuda yang lebih memilih untuk bekerja ketimbang melanjutkan pendidikan dengan alasan tidak adanya biaya. Pendidikan menjadi tidak telalu dianggap penting bagi pemuda outsourcing. Salah satu informan yang menjelaskan hal tersebut adalah Bahrul Ulum, ia tidak melanjutkan pendidikan dan lebih memilih bekerja karena tidak memiliki biaya untuk kuliah "Karena faktor ekonomi, orang tua tidak dapat membayar biaya ke perguruan tinggi. terus saya mengajukan lamaran pada CV. CWN. Kemudian saya disana melakukan tes tulis dan tes fisik dan akhirnya diterima" (wawancara Bahrul Ulum, Februari 2020). Ekonomi keluarga menjadikan pemuda lebih memilih untuk bekerja.

Terdapat beberapa pemuda outsourcing yang sebenarnya menghendaki untuk berkuliah. Witin Arfiani, salah satu informan menyatakan bahwa sebenarnya memiliki keinginan untuk berkuliah.
"Keadaan ekonomi memaksa untuk menjatuhkan pilihan untuk bekerja ketimbang kuliah. Namun dulu juga berkeinginan untuk bekerja sambil berkuliah, namun karena waktu kerja yang panjang tidak memungkinkan untuk melakukan hal tersebut" (Wawancara Witin Arfiani, Februari 2020).

Beberapa pemuda memiliki keinginan untuk berkuliah sambil bekerja, karena jam kerja yang tidak memungkinkan menjadikan keinginan tersebut. Pemuda outsourcing tidak dapat menggapai Pendidikan yang lebih tinggi. Pilihan untuk meninggalakan pekerjaan dan memutuskan untuk kuliah, menimbulkan masalah baru yaitu bagaimana ia membayar biaya kuliah. Akhirnya, pilihan yang paling mungkin untuk di ambil adalah memilih untuk bekerja dan meinggalkan keinginan untuk melanjutkan pendidikan kejenjang yang lebih tinggi. Pemuda Outsourcing dalam masa transisinya terkadang juga mengalami kejadian tak terduga. Semula yang berkeinginan untuk berkulaiah, harus berubah haluan untuk lebih memilih bekerja karena kejadian meninggalnya ayahnya. Kejadian tersebut terjadi pada Rafika Putri, informan tidak jadi melanjutkan daftar kuliah di karenakan ayahnya

"Dulu ada keinginan untuk melanjutkan kuliah, tapi ketika tes SBMPTN bertepatan dengan meninggalnya ayah. Sehingga keinginan tersebut harus di urungkan" (Wawancara Rafika Putri, Februari 2020).

Semula keadaan perekonomian keluarga normal-normal saja, namun pasca meninggalnya ayah informan ekonomi keluarga mengalami kekurangan. informan merasa tidak tega dengan ibunya ketika dirinya memaksakan diri untuk berkuliah. Akhirnya, keinginan untuk berkuliah harus di tinggalkan dan pilihan yang diambil adalah membantu perekonomian keluarga dengan bekerja.

Pemuda outsourcing juga menghadapi lingkungan sosial yang penuh akan persaingan dan lowongan pekerjaan yang terbatas. Mendapatkan pekerjaan idaman mungkin di idamkan oleh semua pemuda, apalagi mendapatkannya pada usia muda. Pekerjaan idaman yang sesuai dengan minat dan keahlian, pekerjaan yang memberikan kontrak dalam jangka yang panjang, pekerjaan yang menjamin keselamatan kerja mereka, semua keinginan tersebut sangat sulit untuk di dapatkan. Perjuangan para pemuda outsourcing di Mojokerto ini mungkin dapat menggambarkan bagaimana persaingan dalam mendapatkan pekerjaan. Zenzogi menjelaskan bahwa untuk mendapat kontrak perusahaan outsourcing dia harus menunggu 4 bulan dan menjalani test yang berlapis

"untuk tes yang harus saya harus lakukan adalah tes kesehatan, tes interview, dan masa trining, dan biaya untuk tes 
kesehatan sendiri sebesar 300 ribu. untuk keseluruhan prosesnya saya harus menunggu 4 bulan sampai saya di panggil kerja" (Wawancara Zenzogi, Februari 2020).

Semua proses tersebut hanya untuk mendapatkan kontrak dengan perusahaan outsourcing dengan jangka waktu satu tahun. Walaupun begitu, ada banyak sekali yang meminati lowongan kerja tersebut. Realita sosial tersebut juga memperngaruhi masa Transisi pemuda, idealisme pemuda untuk mendapatkan pekerjaan idamannya hanya sebatas angan saja.

Pemuda yang tidak sanggup untuk menunggu dan mencari pekerjaan dengan test yang berlapis memiliki caranya sendiri dalam mencari pekerjaan. Calo lowongan pekerjaan adalah pilihan bagi mereka yang menghendaki mendapat pekerjaan secara cepat dan jaminan mendapatkan kontrak kerja. Calo lowongan pekerjaan disini adalah orang yang bekerja pada perusahaan outsourcing yang menyuplai tenaga kerja pada perusahaan tertentu. Kekuasaan yang dimiliki Calo Lowongan pekerjaan tersebut dapat merekrut orang pilihannya untuk langsung tanda tangan kontrak dan bekerja. Hal ini yang di sampaikan oleh Ansori, dalam proses pencarian kerja ansori membayar Calo

\begin{abstract}
"Ya dulu saya masuk ke perusahaan tersebut melalui calo. Jaadi saya bayar uang untuk bekerja pada perusahaan tersebut. ketika saya lulus dari SMK langsung bayar calo, ijaasah belum keluar, akhirnya pakek surat keterangan lulus dari sekolah" (Wawancara Ansori, Februari 2020).
\end{abstract}

Bahkan dalam pengalaman Ansori, sebelum mendapatkan ijasah dan hanya menggunakan SKL (surat keterangan lulus) ia sudah dapat bekerja. Calo lowongan pekerjaan menjadi pilihan yang lain bagi para pencari kerja untuk mendapatkan pekerjaan, walaupun harus membayar upah sebagai uang ganti jasa Calo tersebut. walaupun tidak berbeda dengan yang tidak menggunakan calo, kontrak yang di sodorkan berdurasi tidak panjang, yaitu berkisar 3 bulan.

Pilihan pemuda yang menghendaki menerima pekerjaan dan tanda tangan kontrak secara cepat adalah dengan jaringan perteman. Bagi beberapa pemuda, jaringan pertemanan menjadi modal yang kuat untuk mendapatkan pekerjaan. Vivin menjelaskan bahwa ia mendapat pekerjaan dengan cara meminta bantuan dari temannya yang mampu memberikan kontrak dengan perusahaan tempat ia bekerja sekarang

"Dulu ceritanya ketika saya mencari pekerjaan saya dikasih tau temen kalau temanya dapet memasukkan seseorang untuk bekerja di salah satu pabrik es krim di Mojokerto. Kemudian saya mengajukan lamaran dan akhirnya di terima" (Wawancara Vivin Indah, Februari 2020).

Hubungan pertemanan yang di jalin oleh pemuda dapat membantunya mendapatkan pekerjaan, namun dalam kasus Vivin teman yang dimaksud adalah kenalan yang ia kenal dari teman dekatnya. Jasa tarimakasih yang harus di berikan oleh vivin pada kenalannya tersebut berupa sejumlah uang.

Pemuda Outsourcing Mojokerto memiliki ceritanya masing masing dalam masa transisi menuju dunia kerja. Namun, kesamaan dalam kisah mereka adalah tidak tercapainya pendidikan tinggi bagi mereka, entah itu dari keinginan dari diri pemuda itu sendiri atapun faktor diluar dirinya. Menyelesaikan pendidikan dengan baik merupakan salah satu faktor penting dalam masa transisi pemuda. Dalam melihat trasnsisi pemuda Wyn dan White (1996)terdapat tiga lembaga sosial yang harus di selesaikan dengan baik oleh pemuda dalam masa transisinya, yaitu pendidikan, kerja dan pernikahan. Alih-alih menghakimi proses transisi pemuda Outsourcing dengan gagal atau berhasil, dilihat dari kenyataan yang ada di lapngan masih banyak pemuda yang memiliki keterbatasan dalam menyelesaikan pendidikan dengan baik. Lebih jauh lagi, kita perlu menela'ah, apakah pendidikan sudah memerdekaan seperti yang di katakan oleh paulo freire (1984) yang memerdekakan, atau hanya sebagai bentu proses pencarian ijasah yang menjadi syarat untuk mencari pekerjaan. Hal ini di dasarkan pada kenyataan bahwa para pemuda outsourcing ini menyelesaikan pendidikan sekolah menengah kejuruan dengan jurusan yang beragam, namun itu tidak memberi pengaruh apapun dalam proses pencarian pekerjaan dan pekerjaan yang mereka lakukan. Setidaknya dengan pendidikan yang lebih tinggi mereka dapat memperoleh pekerjaan yang lebih baik dan stabil (Andy Furlong \& Cartmel, 2007) di bandingkan dengan bekerja pada perusahaan outsourcing.

Ketatnya persaingan dan terbatasnya lowongan pekerjaan menjadikan pemuda sulit untuk mencari pekerjaan. Walaupun pekerjaan tersebut harus melalui perusahaan outsourcing, mereka harus menunggu untuk mendapat panggilan pekerjaan. Namun, masih terdapat cara cepat bagi para pemuda yang menghendaki memperoleh pekerjaan secara cepat dan tanpa menunggu, yaitu dengan menggunakan jasa calo dan menggunakan relasi. Kedua cara tersebut bukan untuk mendapatkan pekerjaan yang secara langsung di kontrak oleh perusahaan, namun untuk pekerjaan yang di kontrak oleh perusahaan outsourcing. Dalam masa transisi pemuda, pekerjaan yang layak dan dapat meminimalisir risiko yang akan di perolehnya di masa depan (Beck, 1992). Jaminan karir dan keselamatan kerja, tentu tidak di miliki oleh mereka yang bekerja di perusahaan outsourcing. Kontrak 
paling lama yang diberikan oleh perusahaan outsourcing adalah satu tahun, bahkan pada beberapa informan ada perusahaan yang memberikan kontrak dengan jangka tiga bulan. Jaminan kelelamatan kerja juga tidak diberikan pada pekerja, hanya di jumpai satu perusahaan yang memberikan jaminan tersebut pada pekerjanya. Hal ini dapat menjawab bahwasannya bekerja pada perusahaan outsourcing bukanlah pekerjaan yang tepat untuk pemuda.

\section{Ketidakpastian Masa Depan Pemuda Outsourcing}

Semua orang menghendaki dirinya memiliki masa depan yang baik, tak terkecuali pemuda outsourcing. Pada era modern lanjut, mempersiapkan masa depan penting untuk di lakukan oleh orang yang menghendaki masa depannya terhindar dari risiko yang akan terjadi (Beck, 1992). Era modern lanjut berbeda dengan era modern awal. Jika pada era modern awal individu lebih realtif mudah untuk memperdiksi apa yang akan terjadi pada masa depan, hal itu tidak terjadi pada era modern lanjut yang lebih dinamis dan penuh akan risiko (Azca \& Sutopo, 2013). Perubahan yang dimaskud adalah perubahan terkait bagaimana sistem dunia yang telah berubah terkait dengan adanya perkembangan teknologi yang sangat pesat dan industrialiasi. Lebih lanjut Beck(1992) menjelaskan bahwasanya dalam masyarakar risiko, individu selalu memperjuangkan keamanan dan kepastian dalam hidupnya. Caracara yang di tempuh adalah dengan merencanakan masa depan, manajmen keuangan pribadi dan membeli asuransi.

Risiko tidak hanya diartikan dengan kejadian sosial yang berasal dari luar kontrol manusia, seperti bencana alam atau bencana karena kesalahan teknologi (ledakan reaktor nuklir Chernobyl). Risiko juga mencakup kemiskinan, ketimpangan, dan kurangnya akses terhadap pendidikan (Beck, 1992). Ironinya, risiko juga memihak pada kelas sosial tinggi dalam masyarakat. Semakin tinggi kelas sosial seseorang dalam masyarakat, mereka akan semakin mampu untuk mengontrol risiko yang akan mereka hadapai. Sejarah menunjukkan bahwasanya risiko terdistribusi pada pola kelas sosial yang ada di masyarakat, hanya saja berbading terbalik dengan kekayaan yang terakumulasi pada kelas sosial atas, risiko terakumulasi pada kelas sosial rendah (Beck, 1992).

Meminimalisir resiko yang terjadi pada masa depan, juga menjadi harapan para pemuda outsourcing. Harapan yang dimiliki oleh para pemuda Outsourcing adalah bekerja hingga mereka berumur 55 atau sampai mereka pensiun. Bahrul Ulum menghendaki bahwa dia ingin bekerja sampai pensiun pada perusahaan tempatnya bekerja sekarang "kemungkinan saya bekerja di perusahaan ini ya sampai usia 50 tahun, Ya enjoy aja mas, selagi tidak nganggur. Bekerja pada perusahaan ini enak, santai dan menjalani enjoy" (wawancara Bahrul Ulum, Februari 2020).

Lingkungan kerja dimana tempat kerja informan menjadikannya sudah enjoy menjalani pekerjaan. Pernyataan "selagi tidak nganggur" mengindikasikan bahwa sulitnya mencari pekerjaan tidak ingin lagi di rasakan oleh informan. Keinginan tersebut, juga merupakan bentuk perencanaan yang dilakukan oleh informan dalam era modern lanjut. Namun untuk mewujudkan hal tersebut Informan terlebih dahulu untuk mendaftarkan diri menjadi karyawan tetap pada perusahaan secara langsung. Lagi-lagi, harapan pemuda yang begitu tidak dapat dipenuhi oleh perusahaan Outsourcing, dimana dibiasanya kontrak hanya berlaku paling lama satu tahun dan paling cepat tiba bulan, sesuai dengan kebijakan perusahaan outsourcing tersebut.

Menjadi karyawan tetap tidaklah jaminan dari perusahaan outsourcing. Tidak banyak Perusahaan yang melakukan perekrutan pegawai tetap. Perusahaan lebih memilih menggunakan perusahaan outsourcing untuk memenuhi kebutuhan akan pekerja pada bagian produksi. Banyak sekali keuntungan yang didapatkan perusahaan ketika mereka menggunakan perusahaan outsourcing dalam proses produksi. Biaya pengeluaran perusahaan dapat di tekan, karena dana yang sebelumnya di gunakan untuk memberikan Jaminan pada pekerja dengan menggunakan perusahaan outsourcing tidak perlu lagi mengeluarkan uang tersebut (Triyono, 2011). Akhirnya, perusahaan jarang sekali membuka lowongan pekerjaan, seperti pengalaman yang dirasakan oleh Zenzogi.

\section{"ya kita tau sendiri, untuk menjadi karyawan tetap ya harus bayar telebih dahulu. Nanti ketika bekerja kita akan di tawari untuk menjadi karyawan tetap tapi harus bayar. Dan itupun jarang dan tidaklah murah" (wawancara Zenzogi, Februari 2020).}

Untuk menjadi pegawai tetap para pekerja harus menjadi pegawai outsourcing terlebih dahulu, kemudian jika ada tawaran dan bisa bayar maka pekerja tersebut dapat menjadi pekerja tetap. Pemuda Outsourcing hanya dapat meunggu apa yang lebih cepat datang, lowongan pekerja tetap atau kontrak yang tidak diperpanjang.

Pekerja outsourcing banyak yang tidak terlindungi oleh jaminan BPJS ketenagakerjaan, tak terkecuali para pemuda outsourcing di Mojokerto ini. dari delapan informan, yang menyatakan bahwa mereka tercover BPJS hanyalah dua informan. Perusahaan yang di ikuti oleh Ansori tidak memberikan Jaminan tersebut 
"sesuai UMR di Gersik ya 3,2 juta tiap bulannya. Kita sudah dapat dari CV. Entah sudah di potong atau belum. Namun tidak ada jaminan sama sekali" (wawancara Ansori, Februari 2020).

Tidak adanya jaminan berarti pekerjaan tersebut memiliki risiko yang sangat besar. Jika kita tarik pendapat dari Beck (1992) bahwa individu berusaha untuk meminimalisir risiko di masa depan, maka hal itu tidak dapat di jumpai pada pemuda outsourcing di Mojokerto. Jaminan BPJS tidak semerta-merta menghilangkan risiko individu yang bekerja pada suatu perusahaan, setidaknya dengan adanya BPJS ketika ada kecelakaan kerja biaya rumah sakit dapat terpenuhi dan dalam masa pemulihan individu tersebut dapat memenuhi kebutuhan keluarganya. Penting bagi setiap pekerja untuk memiliki jaminan BPJS, apalagi pada pemuda pekerja yang mana mereka masih memiliki harapan hidup yang panjang dan masa depan yang hendak di wujudkan.

Pemuda dihadapkan pada pilihan yang sulit, mereka menghendaki pekerjaan yang memiliki risiko rendah, disisi lain lowongan yang tersedia hanyalah bekerja pada perusahaan outsourcing. Perusahaan dengan mudahnya untuk merekrut pekerja baru setiap bulannya jika ada pekerja yang memutuskan untuk tidak memperpanjang kontrak. Hak ini di sebebkan banyaknya pengangguran yang meyebabkan daya tawar nilai tenaga kerja sangatlah rendah (Triyono, 2011). Menurut badan pusat statistik, terdapat sebanyak 5,23 persen pengangguran di Indonesia dan pengangguran dengan persentase tertinggi adalah pengangguran yang menamatkan pendidikan Sekolah Mengegah Kejuruan dengan jumlah persentase 10,42 persen (BPS, 2019). Pemuda Outsourcing tidak memiliki nilai tawar tinggi di perusahaan. Perusahaan dapat dengan mudah untuk tidak melanjutkan kontrak dan mencari pekerja yang baru. Pengalamn tersebut pernah dialami oleh Nur Huda "setiap akhir tahun kita akan di evaluasi, ketika kinerja kita baik maka kita akan terus di perpanjang kontraknya. Tapi ketika kinerja kita dibawah strandar mereka, kita dapat dikeluarkan begitu saja" (Wawancara Nur Huda, Februari 2020). Pekerja memiliki tuntutan pekerjaan yang tinggi, namun tidak di imbangi dengan fasilitas yang di berikan perusahaan.

Menjadi pemuda setidaknya dapat dilihat dari dua sisi yang berbeda. Pertama dalam sudut pandang "becoming" yang menempatkan mereka dalam konteks parental and societal expectation (Huijsmans \& Boyden, 2016). Konsep ini berusaha menggambarkan pemuda dalam konteks harapan dari lingkungan sosial di sekitar mereka yang biasanya bersifat baik secara normatif. Sementara pada sisi yang lainnya pemuda juga dikategorikan dalam "being" yang mana mereka berusaha menikmati kehidupan masa muda dari sisi mereka (Huijsmans \& Boyden, 2016). Hal tersebut pun terjadi pada konteks penelitian kali ini, anak-anak muda yang bekerja sebagai buruh outsourcing di beberapa industri memiliki dilemma dalam kehidupan mereka. Pada satu sisi mereka dituntut untuk bekerja sekaligus produktif bagi keluarga. Namun pada sisi yang lain mereka juga sedang menikmati masa muda mereka dengan caranya seperti nongkrong di kafe, berpacaran, ataupun mengotak-atik motor mereka supaya terlihat lebih menarik. "Untuk melepas penat setiap sebulan atau ketika pacar saya senggan saya akan mengajaknya untuk perwisata atau sekedar ke café" (wawancara zenzogi, februari 2020). Beberapa informan juga menjelaskan mereka menyisihkan pendapatannya untuk hobi mereka. Sepetri yang diceritakan oleh Bahrul Ulum, "saya ikut komunitas motor, jadi ada anggaran untuk memperbaiki motor dan modifikasi motor" (wawancara Bahrul Ulum 2020). Pemuda pekerja outsourcing menyisihkan uang hasil kerjanya untuk kesenangan mereka.

Apabila dilihat dari konsep "becoming" and "being" tersebut maka hal yang lumrah ketika pada akhirnya anak-anak muda ini juga tidak berpikir terkait mekanisme outsourcing yang sifatnya relative eksploitatif. Beban jam kerja yang cukup tinggi memang diimbangi pula dengan pendapatan yang berada di atas UMR, namun mereka pada akhirnya kehilangan menikmati masa muda mereka. Meskipun demikian anak-anak muda yang bekerja di industry dengan mekanidme outsourcing ini masih tetap gembira karena dari hasil kerja tersebut mereka dapat menikmati uang yang mereka miliki bersama dengan teman atau sesuai hobi mereka. Kesenangan yang barangkali bersifat sementara akibat hilangnya banyak waktu mereka ketika bekerja.

Pemuda outsourcing di Mojokerto di hadapkan kenyataan bahwasanya banyak alasan untuk tidak menjadikan pekerjaan outsourcing tidak layak untuk menjadi tempat menitipkan masa depan. Risiko diera modern lanjut yang akan semakin kompleks tidak dapat ditaklukkan jika mereka bekerja pada sistem kerja outsourcing. Secara hukumpun, pekerja outsourcing tidak memiliki posisi yang kuat ketika mereka di putus kontrak atau PHK (Prabhaputra, 2019). Dilihat dari realitas sosial yang ada di lapangan, pemuda sangat rentan jika mereka hanya menggantungkan nasibnya di perusahaan outsouring. Pelaksanaan Outsourcing seolah hanya menguntungkan sebelah pihak dan mengabaikan pihak yang lainnya. Walaupun pada kenyataannya outsourcing jika di lakukan dengan benar akan menguntungkan kedua pihak, namun kenyataan di lapangan tidak berkata demikian.

Sementara ini di Indonesai hanya terdapat satu contoh penerapan outsourcing yang menguntungkan kedua belah pihak. Yaitu penerapan Outsourcing di bidang industri keratif. Perkembangan outsourcing dalam indutri kreatif, seperti animasi, digital artist, app developmet dan lain sebagainya terbukti mampu menekan angka pengangguran di Indonesia (Glick et al., 2020). Pengahargaan yang tinggi pada bidang-bidang tersebut menjadikan pihak-pihak 
yang ada dalam lingkaran tersebut di untungkan, tak terkecuali para pekerja online outsourcing atau yang lebih akrab di sebut dengan Freelancer. Hal yang Perlu di lakukan untuk menjadikan outsourcing konvensional di Indonesia dapat semaju Online Outsourcing adalah dengan memberi penghargaan yang lebih pada semua pekerja tak terkecuali.

\section{KESIMPULAN}

$\mathrm{G}$ lobalisasi telah memberikan banyak perubahan pada kehidupan masyarakat secara masif. Perubahan yang paling menonjol ada pada perubahan pada sektor industri, perkembangan IPTEK yang sangat cepat, menjadikan sektor industri saat ini telah memasuki babak revolusi industri 4.0. Perubahan yang sangat cepat yang terjadi didunia saat ini menjadikan individu harus dengan cepat pula beradaptasi dengan perubahan yang dinamis. Salah satu perubahan dinamis yang harus di adapai individu adalah perubahan dalam mencari pekerjaan. saat ini individu tengah berlomba-lomba dalam mencari pekerjaan yang mereka idam-idamkan.

Globalisasi menjadikan banyak sektor dalam kehidupan manusia menjadi lebih mudah dan serba instan. Namun dalam mencari pekerjaan tidak berlaku kemudahan tersebut. Individu harus berlomba-lomba dalam mencari pekerjaan, bahkan lawan dari mereka tidak hanya individu yang lain namun juga robot-robot yang dapat meminimalisir pekerjaan manusia. individu juga harus menghadapi permasalahan klasik dalam dunia kerja di Indonesia, yaitu terbatasnya lapangan pekerjaan.Jika dilihat dari data statistik, angakatan kerja muda berkisar 15-24 tahun mengalami peningkatan yang cukup besar. dapat dikatakan, angakatan kerja yang paling terdampak dengan adanya perubahan sosial yang terjadi karena globaliasai adalah pemuda. Padahal trend yag terjadi saat ini pemuda menghendaki bekerja setelah mereka menyelesaikan jejang pendidikannya, baik itu SMA, SMK, ataupun Perguruan Tinggi. Namun karena banyaknya angkatan kerja di usia tersebut, tidak di imbangi dengan banyaknya lapngan pekerjaan menjadikan pemuda kesulitan dalam menghadapi masa transisinya menuju dunia kerja.

Keadaan dunia kerja yang carut-marut, mendapat angin segar dengan adanya mekanisme sistem kerja outsourcing. Outsourcing di gadanggadang mampu membuka lebih banyak lapangan pekerjaan dan juga dapat menguntungkan perusahaan. Hal ini menjadikan banyak pula pemuda yang akhirnya memutuskan bekerja pada sistem kerja ini. kualifikasi yang tidak terlalu tinggi, tawaran kerja yang banyak, dan bayaran yang lumayan banyak menjadi daya tarik utama pemuda memutuskan untuk masuk dalam sistem kerja tersebut.
Solusi yang ditawarkan outsourcing pada dunia kerja tidak sepenuhnya menyelesaikan masalah. Banyak pemuda yang kemudian harus merelakan masa mudahnya dengan bekerja dalam sistem kerja outsourcing. Sistem kerja outsourcing tidak menjadi ramah bagi pemuda karena sistem kontrak yang terapkan relatif pendek. Perusahaan outsourcing dapat seawaktu-waktu memutus hubungan kerja dengan pekerja, dengan cara kontrak tidak di perpanjang. Banyak dari perusahaan outsourcing tidak memberikan jaminan keselamatan kerja bagi pekerjaannya. Padahal pekerja yang hendak mendaftar harus memiliki kesehatan yang prima sesuai dengan klasifikasi perusahaan. Outsourcing juga tidak dapat memberikan jenjang karir bagi pekerjannya. Pemuda tentu saja menghendaki jenjang karir mereka dalam perusahaan tempatnya bekerja. Sistem kerja Outsourcing senyatanya tidak mampu memberikan pemuda keamanan dan menimimalisir risiko yang dihadapi pemuda di masa depan.

Apabila dilihat sistem kerjanya outsourcing tentu saja tidak menguntungkan bagi pemuda. Mereka tidak dapat menitipkan masa depan mereka pada sistem kerja outsourcing, karena dengan kenyataan yang ada outsourcing tidak dapat meminimalisir risiko yang akan di hadapi pemuda di masa depan. Meskipun demikian pemuda tetap gembira dengan sistem kerja outsourcing. Mereka nyaman dan enjoy dalam bekerja, dan bahkan mereka berencana untuk tetap bekerja hingga usia pensiun mereka. Pemuda cenderung memiliki pemikiran "Being" yang mana mereka berusaha untuk menikmati masa muda mereka. Masa muda mereka dengan bayaran dari perusahaan yang cukup besar menjadikan mereka senang dengan kehidupan mereka saat ini. Kesenangan yang di mikmati saat ini oleh pemuda, barangkali belum tentu mereka dapatkan di masa depan, dimana mereka tidak di perpanjang kontraknya oleh perusahaan. Pemuda pekerja memerlukan perlindungan dari pemerintah, dalam segi hukum dan kebijakan dalam dunia kerja. Outsourcing mungkin memberikan banyak lowongan pekerjaan, namun aspek yang lain yang berkaitan dengan masa depan pemuda tentu tidak boleh di kesampingkan.

\section{E. UCAPAN TERIMAKASIH}

\section{erima kasih penulis sampaikan kepada}

Universitas negeri malang atas kesempatan yang diberikan untuk menulis artikel ini. Tak lupa juga penulis sampaikan kepada pihak-pihak terkait khususnya kepada teman teman pemuda di Mojokerto Yang telah memberikan kesempatan untuk mengumpulkan data yang dibutuhkan dalam penulisan artikel ini. 


\section{DAFTAR PUSTAKA}

Alves, R. dos S., Souza, A. S. de, \& All, E. (2014). Understanding Youth in Late Modernity. Igarss 2014, 1, 1-5. https://doi.org/10.1007/s13398-014-0173-7.2

Anthony Giddens. (2002). Runaway World How Globalization is Reshaping our Lives. Profile Books Ltd.

Azca, M. N., \& Sutopo, O. R. (2013). TRANSISI PEMUDA YOGYAKARTA MENUJU DUNIA KERJA : Previous studies of youth transition are dominated by theories from source of data. Instead of contending that young people is free to make choice.

Badan Pusat Statistik. (2019). Februari 2019: Tingkat Pengangguran Terbuka (TPT) sebesar 5,01 persen. In 2019-05-06.

Beck, U. (1992). Risk Society: Towards a New Modernity (Vol. 17). SAGE.

Beck, U. (2009). World at Risk. Polity Press.

Bertaux, D. (1981). Biography and Society: The Life History Approach in the Social Sciences. SAGE Publications. https://books.google.co.id/books?id=ZKB6AAAAIAAJ

Bima, K., Nggoli, T., \& Provinsi, D. I. (2020). Pengembangan Ekonomi Lokal Melalui industrialisasi Tenunan Khas Bima "Tembe Nggoli" di Provinsi NTB. Jurnal Antropologi: Isu-Isu Sosial Budaya, O2(December), 226-235.

Bonnett, A. (2005). Global America? The Cultural Consequences of Globalization. The British Journal of Sociology, 56(4), 664-665. https://doi.org/10.1111/j.1468-4446.2005.00088_2.x

BPS Jatim. (2019). Keadaan Angkatan Kerja Provinsi Jawa Timur 2018.

Clarke, L., \& Beck, U. (2006). Risk Society: Towards a New Modernity. Social Forces. https://doi.org/10.2307/2579937

Duncan, J. S. (2017). Men without property: The tramp's classification and use of urban space. In Readings in Urban Analysis: Perspectives on Urban Form and Structure. https://doi.org/10.4324/9781315128061

Freire, P. (1984). Pendidikan Segabai Praktek Pembebasan. PT. Gramedia.

Furlong, A., \& Cartmel, F. (1997). Young people and social change : individualization and risk in late modernity. Open University Press. https://eprints.gla.ac.uk/54420/

Furlong, Andy, \& Cartmel, F. (2007). Young people and social change. McGraw-Hill Education. https://books.google.co.id/books?hl=en\&lr=\&id=ZYrNMhz_hE4C\&oi=fnd\&pg=PP1\&dq=Young+people+an $\mathrm{d}+$ social+change\&ots=XO3Qf0vlO8\&sig=YAj6NI3MI19-

YIHWhbG6zQ6eVXA\&redir_esc $=y \# v=$ onepage\& $q=$ Young people and social change\& $f=f a l s e$

Glick, P., Constant, L., Edochie, I., \& Nataraj, S. (2020). Online Outsourcing: Prospects for Increasing Youth Employment and Reducing Poverty in Indonesia. Online Outsourcing: Prospects for Increasing Youth Employment and Reducing Poverty in Indonesia, February. https://doi.org/10.7249/pe271

Hadiz, V. R. (2006). Empire and neoliberalism in Asia. In Empire and Neoliberalism in Asia. https://doi.org/10.4324/9780203964989

Haji Mohamed, A. (2017). GLOBALISASI DAN IMPAK SOSIOBUDAYA. Jurnal Antropologi: Isu-Isu Sosial Budaya. https://doi.org/10.25077/jantro.v19i1.68

Hendrastomo, G. (2010). Menakar Kesejahteraan Buruh: Memperjuangkan Kesejahteraan Buruh diantara Kepentingan Negara dan Korporasi. INFORMASI. https://doi.org/10.21831/informasi.v2i2.6205

Huijsmans, R., \& Boyden, J. (2016). Generationing Development, A Relational Approach to Children, Youth, and Development (R. Huijsmans (ed.)). Palgrave Macmillan.

Hull, G., Zacher, J., \& Hibbert, L. (2009). Youth, risk, and equity in a global world. Review of Research in Education, 33(1), 117-159. https://doi.org/10.3102/0091732X08327746

Moleong, L. J. (2015). Metodologi penelitian kualitatif. Remadja Karya. https://books.google.co.id/ books?id=YXsknQEACAAJ

Naafs, S., \& White, B. (2012). Generasi Antara: Refleksi tentang Studi Pemuda Indonesia. Jurnal Studi Pemuda, I(2), 89-106.

Prabhaputra. (2019). Sistem Outsourcing Dalam Hubungan Industrial Di Indonesia ( Outsourcing System In Industrial Relation In Indonesia ). Jurnal Analogi Hukum, 1(1), $22-27$.

Ritzer, G. (2008). The Blackwell Companion to Globalization (Google eBook). In Blackwell Publishing. https://doi.org/10.1002/9780470691939

STATISTIK, B. P. (2019). Berita Resmi Statistik. https://www.bps.go.id/pressrelease/2019/11/05/1565/agustus2019--tingkat-pengangguran-terbuka--tpt--sebesar-5-28-persen.html\#: :text= Sakernas Agustus 2019 mencatat ada sejumlah $8 \% 2 \mathrm{C} 13$,jam seminggu tetapi tidak mencari pekerjaan atau

Summary, E. (2020). Technology and the future of jobs X Global Employment Trends for Youth 2020 EXECUTIVE SUMMARY. 184.

Susilowati, S. H. (2016). Fenomena Penuaan Petani dan Berkurangnya Tenaga Kerja Muda serta Implikasinya bagi Kebijakan Pembangunan Pertanian. Forum Penelitian Agro Ekonomi. https://doi.org/10.21082/fae.v34n1.2016.35-55

Sutopo, O. R., \& Azca, M. N. (2013). TRANSISI PEMUDA YOGYAKARTA MENUJU DUNIA KERJA: Narasi dan Perspektif dari Selatan. Jurnal Universitas Paramadina, 10(2), 698-719. 
Sutopo, O. R., \& Meiji, N. H. P. (2014a). TRANSISI PEMUDA DALAM MASYARAKAT RISIKO: ANTARA ASPIRASI, HAMBATAN DAN KETIDAKPASTIAN Oki Rahadianto Sutopo Nanda Harda Pratama Meiji. Jurnal Universitas Paramadina, Vol. 11, 1-23. https://repository.ugm.ac.id/135213/1/52-228-1-PB.pdf

Sutopo, O. R., \& Meiji, N. H. P. (2017). Kapasitas Refleksif Pemuda dalam Transisi Menuju Dunia Kerja. JSW: Jurnal Sosiologi Walisongo, 1(1), 1. https://doi.org/10.21580/jsw.2017.1.1.1934

Sutopo, O. R., \& Meiji, N. H. pratama. (2014b). TRANSISI PEMUDA DALAM MASYARAKAT RISIKO: Antara Aspirasi, Hambatan dan Ketidakpastian. Jurnal Universitas Paramadina, 11(3), 1164-1186.

Sutopo, O. R., Putri, R. D., \& Kusumawardhani, K. L. (2019). Aspirasi Pemuda Kelas Bawah dan Reproduksi Sosial Di Jawa Tengah. Jurnal Studi Pemuda, 7(1), 1. https://doi.org/10.22146/studipemudaugm.42254

Triyono. (2011). Outsourcing Dalam Perspektif Pekerja Dan Pengusaha. Ppk-Lipi, 6(1). http://dspace.uii.ac.id

White, B. (2011). Who will own the countryside? Dispossession, rural youth and the future of farming: Valedictory Address delivered on 13 October 2011 on the occasion of the 59th Dies Natalis. October, 130.

White, B. (2013). Does Indonesia Need Corporate Farms? Reflections on Modernization, Efficiency, and The Social Function of Land. Journal of Rural Indonesia, 1(1), 1-14.

White, B. (2015). Generational dynamics in agriculture: Reflections on rural youth and farming futures. Cahiers Agricultures, 24(6), 330-334. https://doi.org/10.1684/agr.2015.0787

Wyn, J., \& White, R. (1996). Rethinking youth. Sage. 